\title{
Peri-implant soft tissue integration of immediately loaded implants in posterior macaque mandible: A histomorphometric study
}

Type:

Article

Abstract:

Background: Today, one critical goal in implant placement is the achievement of optimal soft tissue integration. Reports thus far have demonstrated successful soft tissue preservation in delayed loaded implants placed in anterior jaws. The aim of this study was to histomorphometrically examine the soft tissues around immediately loaded implants placed in the macaque posterior mandible. Methods: Splinted crowns on screw-shaped titanium implants $(8 \mathrm{~mm}$ length, $3.5 \mathrm{~mm}$ diameter) were utilized. Three implants each were placed in the premolar-molar edientulous mandibular segments of 6 adult monkeys (Macaca fascicularis); one side served as the control (delayed loading) and the other as the test sites (immediate loading). The animals were sacrificed after 3 months of loading. Histomorphometry of 6 soft tissue indices including the sulcus depth (SD), junctional epithelium (JE), connective tissue contact (CTC), biologic width (BW = $\mathrm{SD}+\mathrm{JE}+\mathrm{CTC}$ ), DIM (distance between the implant top and coronal gingiva), and DIB (distance between the implant top and first implant-to-bone contact) was performed on non-decalcified sections. Results: No significant differences in the mean soft tissue scores $(\mathrm{mm})$ between the test $(\mathrm{SD}=0.68+/-0.63$; JE $=1.71+/-1.04 ; \mathrm{CTC}=1.51+/$ 1.14; $\mathrm{DIM}=2.27+/-1.18$; $\mathrm{DIB}=1.32+/-1.21$; $\mathrm{BW} 3.9)$ and control $(\mathrm{SD}=0.88+0.57$; $\mathrm{JE}=1.66+0.77$; CTC $1.24+/-0.92 ; \mathrm{DIM}=2.38+/-0.81$; DIB = $1.19+/-0.91$; BW 3.78) groups were observed $(P>0.01)$. Conclusion: These findings suggest that the dimensions of the peri-implant soft tissues were within the biologic range and were not influenced by immediate functional loading or posterior location of the implants in the macaque mandible.

\begin{tabular}{|c|c|}
\hline Author & $\begin{array}{ll}\text { - } & \text { Siar, C. H. } \\
\text { - } & \text { Toh, C. G. } \\
\text { - } & \text { Romanos, G. } \\
\text { - } & \text { Swaminathan, D. } \\
\text { - } & \text { Ong, A. H. } \\
\text { - } & \text { Yaacob, H. } \\
\text { - } & \text { Nentwig, G. H. }\end{array}$ \\
\hline Source & Journal of Periodontology \\
\hline ISSN & 0022-3492 \\
\hline DOI & 10.1902/jop.2003.74.5.571 \\
\hline Volume (Issue) & $74(5)$ \\
\hline Page & $571-578$ \\
\hline Year & 2003 \\
\hline
\end{tabular}


Keyword:

animal studies,dental implants, immediate loading,peri-implant soft tissues,soft tissue indexes, titanium dental implants, biologic width in-vivo,dog, multicenter, junction, barrier, monkeys, mucosa,bone

Please Cite As:

SIAR, C. H., TOH, C. G., ROMANOS, G., SWAMINATHAN, D., ONG, A. H., YAACOB, H. \& NENTWIG, G. H. 2003. Peri-implant soft tissue integration of immediately loaded implants in posterior macaque mandible: A histomorphometric study. Journal of Periodontology, 74, 571-578.

URL:

- http://apps.webofknowledge.com search via Accession No >>000187315000001

- http://www.ncbi.nlm.nih.gov/pubmed/12816287

- http://www.joponline.org/doi/abs/10.1902/jop.2003.74.5.571\%20?url ver=Z39.882003\&rfr id=ori:rid:crossref.org\&rfr dat=cr pub\%3dpubmed 